\title{
Development of Mathematical Learning Materials Based on Model Eliciting Activities Approach to Improve the Mathematical Reasoning Ability Student Class X SMA Padang
}

\author{
Irwan \\ State University of Padang \\ West Sumatra, Padang \\ irwan.math.165@gmail.com
}

\begin{abstract}
The mathematical reasoning ability of pupils encountered in some schools is still not optimal. One of the attempts to overcome the problem is by developing a mathematics learning material with Model Eliciting Activities (MEAs) approach. Then do development research in order to produce learning materialbased approach MEAs. From the results of preliminary research obtained by the device in accordance with the characteristics of students, in accordance with the applicable curriculum, the sequence of discussion of the material based on the results of concept analysis. This learning material will have an impact on improving students' mathematical reasoning ability.
\end{abstract}

Keywords-Mathematical learning material, MEAs approach, mathematical reasoning ability

\section{INTRODUCTION}

Mathematics plays a very important role in our lives. This is because mathematics is a tool for developing ways of thinking, with abstract ideas and concepts, reasoning being deductive and concerned with structured ideas whose relations are arranged logically [1]. In addition, mathematics is also needed to meet practical needs and solve problems. For example, for them to count, can collect, present, process data, and interpret data. In addition, mathematics can also help understand other fields of study such as physics, chemistry, economics, and so forth. Therefore, mathematics becomes a lesson learned at every level of education.

Mathematical reasoning is one of the abilities that students are expected to have in learning mathematics [2]. Mathematical reasoning is an important component of learning mathematics and is a tool for understanding abstraction [3]. While [4] explains that mathematical reasoning is an integral part of problem solving. If it is associated with thinking, then mathematical reasoning is a major component of thinking that involves the formation of generalizations and illustrates a valid conclusion about the idea and how the ideas are linked [4].

Mathematical reasoning can also be seen as a dynamic activity that involves a variety of ways of thinking in understanding ideas, formulating ideas, finding relationships between ideas, illustrating conclusions about ideas and relationships between ideas. Mathematical reasoning occurs when students: 1) observe patterns or regularities, 2) formulate generalizations and conjectures with respect to observed regularity, 3) assess/test conjecture; 4) construct and evaluate mathematical arguments, and 5) describe (validate) the logical conclusions of a number of ideas and their associations [2], [4]. In this paper mathematical reasoning is the process of making conclusions about a number of ideas and their relevance in solving math problems.

Based on the statements that have been described by some experts, it is deemed necessary to create a mathematics learning that can improve the ability of mathematical reasoning. In fact mathematics learning is developed with theoretical learning patterns, giving examples of problems, and exercises. Learners record every concept of the material delivered by understanding or not with what is recorded. In fact, they are less able to apply the concepts that exist on the record again when given the exercise question. The unsatisfactory condition, manner, and result of mathematics learning is also expressed by some experts. In learning mathematics learners only imitate and record the solution of the problem of teachers [5]. Learners are only told by the teacher, they do not explore their own knowledge they get. Mathematics lessons involve learners active learning, less emphasis on understanding learners and they only accept teacher explanations [6]. Learning activities such as this make learners tend to rote learning or learning to memorize and without understanding or without understanding what is taught by the teacher, so that learning becomes meaningless [7].

In addition to the learning process, other factors that cause the low ability of students' mathematical reasoning is because the student's worksheet has not been supported. Based on the observations made, the student's worksheet used in the school contains a summary of materials and exercise questions. The material presented is a short form containing the necessary formulas in the topic covered. The questions presented are a matter of calculation. Few of the questions presented are questions relating to issues related to the day-to-day life of the learner and questions that are both problem solving and reasoning. 
Learning in schools can still be optimized to improve students' mathematical reasoning abilities. One way that can be done is through the approach of Model Eliciting Activities (MEAs). MEAs are a learning approach for understanding, explaining, and communicating the concepts contained in a problem presentation by presenting a modeling [8]. By presenting this model, it will provide great opportunities for learners to exploit their knowledge in learning mathematics. By using MEAs, learning becomes meaningful because learners can relate the concepts they learn with familiar concepts [9].

Learning with this MEAs approach, requires students to work in small groups of 3-4 learners [10]. Through group work, learners have the opportunity to discuss, express ideas or opinions through words, and listen to ideas or opinions of friends. The main thing in learning MEAs is the activity of creating mathematical models. Creation of a mathematical model requires a powerful concept of understanding the problem so as to help learners transform their minds. Mathematical model can be interpreted as a presentation of a situation or objects in mathematical form. Through modeling, learners will be familiarized with the stages in modeling that simplify the problem, create a mathematical model, transform and solve problems with the model, then interpret the results. This is consistent with the results of several studies that suggest that MEAs have the potential to improve the problem-solving ability of learners [11]. Further MEAs are useful for improving the problem solving of learners [12]. It has also been said that the application of these MEAs can improve the representation and problem-solving skills of learners [13]. The same is stated by [14] and [15].

In the process of implementation, learning with MEAs approach that needs to be equipped with learning tools that can support the achievement of expected goals, such as RPP and student's worksheet. Student's worksheet in this study contains guidelines and collection of questions that have been packaged in such a way that learners not only get routine questions that are usually given by teachers. Student's worksheet using this MEAs approach contains problems related to the daily life of learners, so that learners more easily understand each problem given. The student's worksheet also contains command questions that can guide learners from understanding the problem, designing a model of each given problem so they can present the mathematical idea by translating the problem into images, symbols, and mathematical equations, until completion of the problem. Through student's worksheet based on MEAs approach is expected to improve students' mathematical reasoning ability.

This study discusses how the characteristics of learning material based on the MEAs approach to improve the mathematical reasoning ability of high school X students based on the MEAs approach to improve students' mathematical reasoning abilities. The purpose of this study is to describe the learning material based on the MEAs approach to improve the students' mathematical reasoning abilities based on preliminary research.

\section{METHODS}

This research is the development research, which aims to produce set of learning material in accordance with the conditions of student needs. The development model used adapted from the Plomp's model consisting of 3 stages, namely preliminary research, prototype development or prototyping phase, and assessment phase [16]. In this study developed a mathematics learning device in the form of lesson plan and student's worksheet for high school X class students based on the results of initial investigation.

Preliminary research is conducted by identifying and analyzing what is needed to develop learning tools with the MEAs approach. The purpose of this stage is to obtain a temporary picture of the product to be developed. At this stage the needs analysis, curriculum analysis, learner analysis, and concept analysis are intended to obtain a picture of the problems that occur in the learning of mathematics as a basis for determining alternative solutions and product specifications required, to know the learning materials coherent in accordance with the learning the MEAS approach, to find out the tools that match the characteristics of the learner, as well as to know the scope of content on the device to be developed.

The subjects of the study were the students of grade $\mathrm{X}$ SMA Negeri Padang with the characteristics of low, medium and high ability students. The research data were collected through core competence and basic competence analysis, Concept Analysis, and Student Questionnaire, Interview Guidance, and observation guide.

\section{RESULTS AND DISCUSSION}

In the needs analysis phase, information gathering was done by observing the mathematics learning activities in the classroom and the interview with the mathematics teachers. Based on the results of needs analysis that has been done, it was concluded that learners need learning that can meet the needs of learners who like to be actively involved in learning that was with the discussion of learning in groups. It was necessary to develop an lesson plan and student's worksheet that are equipped with real problems that can guide them to construct their own knowledge. So that learners more easily understand the concept of learning and not memorize the material. Teachers need a learning material that aligns to increase the activities of learners in constructing their knowledge, so as to improve mathematical reasoning ability.

In the curriculum analysis phase, it was analyzed the curriculum used in the school for the subjects of semester 1 class X SMA. This analysis was conducted to study the range of learning materials and learning objectives that can be used as a basis for developing learning material with the MEAs approach. Based on the results of analysis conducted on basic competence and indicators of achievement of competence, there werw no change in the order of basic competence and indicators that have been set in the previous 2013 curriculum. This was because the basic competence was arranged accordingly based on the level of difficulty of the material. Starting from knowing the absolute price form, the equation 
involving the absolute price of algebra, rational inequality, the system of linear equations of three variables, the system of inequality of two variables, the function.

In the stage of analysis of learners made observations of the learning process in the classroom and giving questionnaires to learners to know their characteristics. The questionnaire provided contains items that were used to know the interest, the level of thinking, the tendency to learn, and others that can describe the characteristics of high school X class students. Based on the results of observations and questionnaires given, it can be concluded some characteristics of the learners based on the results of the analysis conducted, that class X high school students were already in the formal operating phase based on their age range. Furthermore, from the learning style, learners prefer to study with peers and they also tend to learn in groups. Other characters found were the learners are still less focused and less active in learning mathematics. Based on the character of the learners encountered, it will develop learning tools that can facilitate the habits of learners and accommodate the character possessed by learners to a more positive direction.

Conceptual analysis aims to determine the objectives and subject matter needed in the development of learning tools. This was done by identifying the key concepts that are taught, detailing and organizing them systematically. The main material in this study is the absolute price, the equation involving the absolute price of algebra, rational inequality, the system of linear equations of three variables, the system of inequality of two variables, the function. Based on the results of initial investigation, the mathematics learning tool developed with the approach of MEAs that can improve students' mathematical reasoning ability. Furthermore, the process of developing lesson plan and student's worksheet with MEAs approach.

Lesson plan was designed as a guide for teachers in implementing the learning process. lesson plan was based on core competenc, basic competence consisting of several indicators. The lesson plan component was designed based on goverment regulation. Learning activities presented in the lesson plan refer to the steps and principles of learning with the approach of MEAs. Presentation of the lesson plan identity, core competencies, basic competencies, the formulation of competency achievement indicators, learning objectives, learning materials, approaches and methods of learning, assessment, and learning resources were designed almost the same as lesson plan in general. Lesson plan components that are characteristic of lesson plan with the MEAs approach were among others can be observed in the steps of learning activities.

In the core activities carried out the learning in accordance with the steps of learning with the approach of MEAs. The lessons plan was designed to facilitate the fulfillment of the principles of the MEA approach. Learning with the MEAs approach consists of five learning steps. The first step, the learning begins with the teacher asks students to read and understand the stories/articles given on the sheet of problems contained in student's worksheet. The story presented is related to the daily life of learners. So in the first step is expected to facilitate the fulfillment of the principle of the MEAs approach is the principle of reality.

The second step is that learners respond to questions given based on the story. The question here is the readiness question presented in the article contained in student's worksheet which is useful to introduce the context of the problem to the learners so that they get an idea of the problems to be solved. The third step is, the teacher asks the learners to read the given problem and make sure each group understands the problem given in the problem sheet.

The fourth step of learning MEAs is that learners try to solve problems to produce the model as the final solution of the problem. In this step, learners discuss and try to construct the model to solve the problem so that the fulfillment of MEAs learning principles is The Model Construction or the principle of model construction.

The contents of the student's worksheet were prepared by taking into account the learning with the MEAs approach. MEAs approac steps, MEAs priciples, and MEAs essential components are illustrated in the designed student's worksheet. So by using student's worksheet can facilitate learners maximally in learning mathematics with approach of MEAs in accordance with lesson plan which have been designed.

On the start page of student's worksheet there are instructions for using student's worksheet which is used as a guide for learners in learning using student's worksheet. Student's worksheet with the approach of MEAs begins by presenting an article related to the problems to be solved by the learners. This is in accordance with the first step of learning with the MEAs approach to the designer of lesson plan. In the article there are also some questions that in the MEAs learning is called the readiness question.

The next part of student's worksheet is a problem that must be solved by the learner. In the problem section there is an order in which learners are instructed to work in the group and discuss the issues given. This is in line with the learning with the MEAs approach that is implemented in groups. Based on the problem given, it is hoped learners can produce model as solution. So the principle of model construction in MEAs learning can be fulfilled.

The student's worksheet provides a place for learners to document the model they get based on the outcome of the discussion they are doing. This facilitates the fulfillment of the model documentation principle. Furthermore, in student's worksheet there is a command to re-examine the solutions that have been obtained by learners. So with this activity is expected to facilitate the implementation of MEAs learning principles that is the self evaluation principle. Here is an example of a problem section presented in student's worksheet and an example of checking back on student's worksheet. 
Masalah 3.3

Sebuah pabrik sepatu memiliki tiga buah mesin yaitu $A, B$ dan $C$. Dalam sehari mesin dapat memproduksi 295 sepatu. Jika hanya mesin A dan B yang bekerja, akan diproduksi 205 sepatu. Jika hanya mesin $A$ dan $C$ yang bekerja akan dipraduksi 185 sepatu. Jika hanya mesin 8 dan $C$ yang bekerja, akan dihasilkan sepatu sebanyak ?

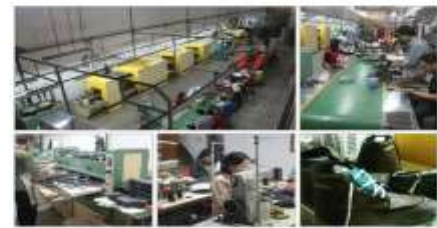

Gambar 1.5 Pabrik Sepatu

1. Tuliskan informasi yang diketahui pada Masalah 3.3 ke model matematika menyatakan jenis mesin dengan menggunakan variabel yang Ananda inginkan I -

r Peniks kembali, apsah jawson Ananda dy

Fig 1. Example of Student's Worksheet

The next part of student's worksheet are activities that facilitate the learners to make a conclusion of the problems they have solved. This concluding activity is an implementation of one of the principles of the MEAs approach: the simple prototype principle in which the solution of the problems that the learners have gained is referred to as a simple prototype that will be reused in different situations.

Reusing the previously obtained solution is called the Construct shareability and reusability principle. In student's worksheet activities that facilitate the fulfillment of these principles is on the activities of learners doing the exercise questions.

\section{CONCLUSIONS AND RECOMMENDATIONS}

The results showed that the learning tools of mathematics with MEAs approach developed were in accordance with the data of the preliminary research results, namely curriculum analysis, concept analysis, student analysis. The problems that exist in student's worksheet are also prepared based on mathematical reasoning indicators of learners. Based on the above conclusions, learning material with the MEAs approach can be used as an alternative mathematical learning material especially to improve mathtematical resoning ability.

\section{REFERENCES}

[1] Hudojo, H. 2003. Pengembangan Kurikulum dan Pembelajaran Matematika. Jakarta: Direktorat Jendral Pendidikan Tinggi.

[2] NCTM. 2000. Principles and Standards for School Mathematics. Reston, VA: NCTM

[3] Russell, S. J. 1999. Mathematical Reasoning in the Elementary Grades. In L. V. Stiff. \& F. R. Curcio (Eds.), Developing Mathematical Reasoning in Grades K 12 (pp.1-12). Reston, VA: NCTM

[4] Artzt, A.F. dan Yaloz-Femia, S. (1999). Mathematical Reasoning during Small-Group Problem Solving. Dalam Stiff dan Curcio (eds). Developing Mathematical Reasoning in Grades K-12. Reston, Va: NCTM.

[5] Rif'at, M. 2001. Pengaruh Pola-Pola Pembelajaran Visual dalam Rangka Meningkatkan Kemampuan Menyelesaikan Masalah-masalah Matematika. Disertasi. PPS UPI. Bandung

[6] Mettes, C.T.W. 1979. Teaching and Learning Prob lem Solving in Science A General Strategy. Interna tional Journal of Science Education, 57(3), 882-885, [Online] (http://doc.utwente.nl/93379/1/ed057p882. pdf, diakses 1 September 2015)

[7] Lesh, R., Hoover, M., Hole, B., Kelly, A., Post, T. 2000. "Principles For Developing Thought-Revea ling Activities For Students and Teachers"; dalam A. Kelly, R. Lesh (Eds), Research Design in Mathema tics and Science Education (hlm. 591-646). Law rence Erlbaum Associates, Marwah, New Jersey

[8] Lesh, Ricard A., Doerr, Helena M., 2003. Beyond Constructivism: Model and Modeling Perspective on Mathematics Problem Solving, learning, and tea ching. Routledge.

[9] Chamberlin, Scott A., \& Moon, Sidney M. 2008. How does the problem based learning approach compare to the model-eliciting activity approach in mathematics?. International Journal for Mathematics Teaching and Learning. [online] (http://www.cimt. plymouth.ac.uk/journal/chamberlin.pdf. diakses 1 September 2015)

[10] Ekmekci, A. \& Krause G. 2011. Model Eliciting Activities (MEAs). $5^{\text {th }}$ Annual UTeach Institute-NMSI Conference, May 26, 2011.

[11] Clark. R. M. Shuman, L.J. Sacre, M. B. \& Yildirim T. P. (2008). Use of Model Eliciting Activities to Improve Problem solving by Industrial Engineering Students. Proceedings of the 2008 Industrial Engineering Research Conference. J. Fowler and S. Mason, eds. Pittsburgh, USA: Departement of Industrial Engineering, University of Pittsburgh.

[12] Yu, S \& Chang, C. 2009. What did Taiwan mathematics Theacher Think of Model-Eliciting Activities and Modeling? International Conference on the Teaching of Mathematical Modeling and Applications, ICTMA Vol 14, University of Hamburg.

[13] Hanifah. 2015. Penerapan Pembelajaran Model Eliciting Activities (MEA) dengan Pendekatan Saintifik untuk Meningkatkan Kemampuan Representasi Matematis Siswa. Tersedia pada: http://journal.unnes.ac.id/nju/index.php/kreano

[14] Dede A T, Hidiroğlu Ç N, and Güze E B. 2017. Examining of Model Eliciting Activities Developed by Mathematics Student Teachers. Journal on Mathematics Education. (Electronic Material Vol 8 No. 2, July, pp. 223 242. DOI: http://dx.doi.org/10.22342/-jme.8.2.3997.223-242

[15] Lubis N H, Pulungan P S, Fauzi A KMS 2017 Model Eliciting Activities (MEA) Application in Online Group Discussion for Mathematics Learning. International Journal of Science and Research (Online) Volume 6 Issue 7.

[16] Plomp, T dan N. Nieven. (2013). Educational Design Research. Enshede: Netherlands Institude for Curiculum Development (SLO). 